\title{
Corticosterone Measurement
}

National Cancer Institute

\section{Source}

National Cancer Institute. Corticosterone Measurement. NCI Thesaurus. Code C79434.

The determination of the amount of corticosterone present in a sample. 